\title{
SUSCEPTIBILITY OF Podisus nigrispinus (DALLAS) (HETEROPTERA: PENTATOMIDEA) TO GAMMA- CYHALOTHRIN UNDER LABORATORY CONDITIONS
}

\author{
Alexandre Igor de Azevedo Pereira ${ }^{1}$; Francisco de Sousa Ramalho ${ }^{2 *}$; José Cola Zanuncio ${ }^{3}$ \\ ${ }^{1}$ UFPB/CCA - Universidade Federal da Paraiba - 58000-000 - Areia, PB - Brasil. \\ ${ }_{3}^{2}$ Embrapa Algodão/Unidade de Controle Biológico, C.P. 174 - 58107-720 - Campina Grande, PB - Brasil. \\ ${ }^{3} U F V$ - Depto. de Biologia Animal - Viçosa, MG - Brasil. \\ *Corresponding author <ramalhohvv@globo.com>
}

\begin{abstract}
Podisus nigrispinus (Dallas) (Heteroptera: Pentatomidae) is an important biological control agent of the cotton leafworm [Alabama argillacea (Hübner)] in the cotton crops in Brazil. The use of selective products such as pyrethroids has been emphasized in this agroecosystem. Then, the susceptibility of the predatory stinkbug P. nigrispinus to the pyrethroid insecticide gamma-cyhalothrin was studied in the laboratory. Nymphs and adults of the predator were exposed to seven concentrations of the gamma-cyhalothrin via topical contact and ingestion through treated water. The concentrations studied of this insecticide via topical application were relatively harmless for adults of $P$. nigrispinus (females: $\mathrm{LC}_{50}=143.5 \mathrm{ppm}$ a.i., and males: $\mathrm{LC}_{50}=145.1 \mathrm{ppm}$ a.i.) and 5th-instar nymphs $\left(\mathrm{LC}_{50}=103.9 \mathrm{ppm}\right)$ as compared to via ingestion (females: $\mathrm{LC}_{50}$ $=1.98$ ppm a.i., males: $\mathrm{LC}_{50}=1.91$ ppm a.i., and 5th-instar nymphs: $\mathrm{LC}_{50}=2.05 \mathrm{ppm}$ a.i.). The use of pyrethroids and beneficial insects in IPM programs should be better evaluated.
\end{abstract}

Key words: cotton, biological control, pyrethroid, selectivity, natural enemies

\section{SUSCETIBILIDADE DE Podisus nigrispinus (DALLAS) (HETEROPTERA: PENTATOMIDAE) A GAMMA-CYHALOTHRIN SOB CONDIÇÕES DE LABORATÓRIO}

\begin{abstract}
RESUMO: Podisus nigrispinus (Dallas) (Heteroptera: Pentatomidae) é um importante agente de controle biológico do curuquerê [Alabama argillacea (Hübner)] na cultura do algodão no Brasil. O uso de produtos seletivos tais como piretróides tem sido enfatizado no agroecosistema do algodoeiro. Portanto, estudou-se em laboratório a suscetibilidade do percevejo predador Podisus nigrispinus (Dallas) ao inseticida piretróide gamma-cyhalothrin. As exposições via ingestão e aplicação tópica de ninfas de $5^{\circ}$ ínstar, fêmeas e machos de P. nigrispinus a gamma-cyhalothrin foram feitas, usando-se sete concentrações do inseticida. Gammacyhalothrin via aplicação tópica foi relativamente menos tóxico às formas adultas de $P$. nigrispinus (fêmeas: $\mathrm{CL}_{50}=143,5$ ppm i.a. e machos: $\mathrm{CL}_{50}=145,1$ ppm i.a. $)$ e às ninfas de $5^{\circ}$ ínstar $\left(\mathrm{CL}_{50}=103,9 \mathrm{ppm}\right)$ desse predador, quando comparado a sua utilização por ingestão (fêmeas: $\mathrm{LC}_{50}=1,98$ ppm i.a., machos: $\mathrm{LC}_{50}=1,91$ ppm i.a. e ninfas de para ninfas de $5^{\circ}$ instar: $\mathrm{LC}_{50}=2,05 \mathrm{ppm}$ i.a.). Os resultados dessa pesquisa sugerem que o uso de piretróides em programas de MIP deve ser avaliado com bastante cautela.

Palavras-chave: algodão, controle biológico, piretróide, seletividade, inimigo natural
\end{abstract}

\section{INTRODUCTION}

Integrated Pest Management in cotton is based mainly on the action of predators (Whitcomb \& Bell, 1962; Ramalho, 1994), and parasitoids (Ruberson et al., 1994; Ramalho et al., 2000) to suppress pest populations. Insecticides are used only when pest populations threaten to exceed the economic threshold. Investigations on sideeffects of insecticides and other pesticides play a crucial role in IPM programs, when chemical and biological measures are used in combination against pests (Mohaghegh et al., 2000, Zanuncio et al., 2003). Then, the insecticides should be effective against insect pests, but relatively safe to natural enemies, and that requires knowing the complex of natural enemies affecting key pests species and the impact of insecticides on these organisms (Campbell et al., 1991).

Biological control has many advantages over other control methods because it is safe, permanent, and economic when correctly used (Stehr, 1982). However, natural enemies may be affected by insecticide sprays via contact with residues, or indirectly through contaminated food or water (Mestdagh et al., 1996). Behavioral and pesticide processes may contribute to differences on susceptibility of predaceous insects and their preys to insecticides (Boyd \& Boethel, 1998). 
Podisus nigrispinus (Dallas) (Heteroptera: Pentatomidae) is an important natural enemy of cotton crop pests in Brazil (Medeiros et al., 2000; 2003). Because of poisoning risks, the use of selective products such as pyrethroids has been emphasized in this agroecosystem (Tillman \& Mulrooney, 2000).

Smagghe \& Degheele (1995) studying the effects of RH 5849 and RH 5992 (tebufenozide) on $P$. nigrispinus, concluded that their nymphs did not show sensitivity to oral treatment (feeding on treated prey) or topical exposure. According to Picanço et al. (1997), permethrin, followed by deltamethrin and methil parathion were the most selective insecticides to $P$. nigrispinus by contact exposure, in comparison to other groups of insecticides. The selectivity of chemical products to P. nigrispinus have been studied; however, few researches analyzed side-effects of pyrethroids on this predator. In this work the susceptibility of $P$. nigrispinus to the new pyrethroid insecticide gamma-cyhalothrin was studied in the laboratory.

\section{MATERIAL AND METHODS}

Insects - Newly molted 5th-instar nymphs ( $\leq 24 \mathrm{~h}$ old $)$, and male and female adults $(\leq 24 \mathrm{~h}$ old) of Podisus nigrispinus were obtained from the mass rearing facility of the Biological Control Unit (BCU)/Embrapa Algodão, Campina Grande, State of Paraíba, Brazil. The insects were maintained in growth chambers at $26^{\circ} \mathrm{C}, 60 \pm 10 \%$ relative humidity, and $12 \mathrm{~L}: 12 \mathrm{D}$ photoperiod. The prey used to feed this predator was larvae of Musca domestica L. (Diptera: Muscidae) originated from colonies at BCU.

Chemical - Gamma-cyhalothrin 15\% suspension concentrate (SC) ((S)-a-cyano-3-phenoxybenzyl(Z)-(1R,3R)-3( 2-chloro-3,3,3-trifluoripropenyl)-2, 2 dimethylcyclopropanecarboxylate) was supplied by Dow AgroSciences Industrial Ltda, Brazil. Gamma-cyhalothrin is the isolated active isomer of lambda-cyhalothrin.

Topical Toxicity - Seven concentrations of the gammacyhalothrin $(11.7,23.4,46.9,93.8,187.5,375.0$, and $750.0 \mathrm{ppm}$ a.i for 5 th-instar nymphs, and 23.4, 46.9, 93.8, $187.5,375.0,750.0$, and $1.500 \mathrm{ppm}$ a.i for adult females and males) were topically applied on individuals of $P$. nigrispinus. One microliter of each concentration of this insecticide diluted in water was applied using a micro syringe on the thoracic dorsum of newly molted 5th-instar and adults of this predator; $1 \mu \mathrm{L}$ of water was used as control. Insects were individually placed in small plastic cups $(7.0 \mathrm{~cm}$ height; $10 \mathrm{~cm}$ diameter) with a hole in their cover. A total of 224 females, 230 males, and 250 5thinstar nymphs were used in the topical toxicity assay. A $2.5 \mu \mathrm{L}$ plastic tube with distilled water and plugged with cotton was inserted in its hole. To supply water to the predator and to maintain the humidity inside the cups. In- dividuals of $P$. nigrispinus received $M$. domestica larvae immediately after treated with the gamma-cyhalothrin. Nymphs of this predator were checked for mortality every $24 \mathrm{~h}$ until eight days after molting and survival of adults was monitored up to eight days after emergence. Mortality included dead individuals and those without movements.

Oral Toxicity - Individuals of $P$. nigrispinus were exposed to the following concentrations of gammacyhalothrin: $0.47,0.94,1.88,3.75,7.50,15.0$, and 30.0 ppm a.i by ingestion through treated drinking water. The insecticide solution was offered to the predators through $2.5 \mathrm{~mL}$ cylindrical plastic tubes, inserted in the cover of each cup of $7.0 \mathrm{~cm}$ height and $10 \mathrm{~cm}$ diameter. Two hundred and fourty five, 5th-instar nymphs, 280 males and 270 females were used in the oral toxicity study. Control groups received distilled water. During the first 24 hours, no food was supplied to stimulate the drinking behavior of P. nigrispinus.

P. nigrispinus were fed with $M$. domestica larvae just after treated with the gamma-cyhalothrin. Mortality of nymphs of this predator was evaluated up to eight days and its adults until eight days old. Mortality included dead individuals and those without movements. Only the mortality data at eight days post-application of the insecticide were submitted to probit analysis.

Statistical Analysis - Data were analyzed by probit analysis (Finney, 1971) using probit procedures (SAS Institute Inc., 2003), and significance was assessed by the degree of overlap of $95 \%$ CL, i.e., no overlap indicates a significant difference at $P \leq 0.05$.

\section{RESULTS}

P. nigrispinus was affected by the gammacyhalothrin (Figures 1-3, Table 1). The mortality of $P$. nigrispinus over the time increased at different percentages (Figures 1-3). Final percentages of mortality for 5th-instar nymphs (at $750 \mathrm{ppm}$ a.i) (Figure 1), female adults (1.500 ppm a.i) (Figure 2), and male adults (1.500 ppm a.i) (Figure 3) of $P$. nigrispinus, exposed to gamma-cyhalothrin by topical application were $96.5 \%, 90.0 \%$, and $90.1 \%$, respectively. The percentages of mortality for 5 th-instar nymphs (at $30 \mathrm{ppm}$ a.i), female adults (30 ppm a.i), and male adults (30 ppm a.i) of P. nigrispinus exposed to gammacyhalothrin by ingestion at 8 days post-application were $98.8 \%, 100.0 \%$, and $100.0 \%$, respectively (Figures 1-3). Values of the $\mathrm{LC}_{50}$ of gamma-cyhalothrin via topical application were 103.9, 143.6, and 145.2 ppm a.i for 5th-instar nymphs, female and male adults, respectively (Table 1). On the other hand, these values were 2.0, 2.0 and 1.9 ppm a.i for 5 th-instar nymphs and female and male adults of $P$. nigrispinus, respectively after exposure to the gammacyhalothrin via ingestion (Table 1). 
Table 1 - Toxicity of the gamma cyhalothrin to 5th-instar nymphs and adult females and males of Podisus nigrispinus (Heteroptera: Pentatomidae) via topical exposure and ingestion at $26^{\circ} \mathrm{C}$, relative humidity of $60 \pm 10 \%$, and a photoperiod of 12L:12D.

\begin{tabular}{|c|c|c|c|c|c|c|c|c|}
\hline $\begin{array}{l}\text { Application } \\
\text { method }\end{array}$ & Stage & $\mathrm{n}$ & Slope \pm SE & $\mathrm{LC}_{10}(95 \% \mathrm{FL})$ & $\mathrm{LC}_{50}(95 \% \mathrm{FL})$ & $\mathrm{LC}_{90}(95 \% \mathrm{FL})$ & $\chi^{2} ; P>0$ & $\mathrm{df}$ \\
\hline \multirow[t]{3}{*}{$\begin{array}{l}\text { Topical } \\
\text { exposure }\end{array}$} & $\begin{array}{l}\text { 5th-instar } \\
\text { nymph }\end{array}$ & 250 & $1.62 \pm 0.12$ & $16.74(11.73-30.35)$ a & $103.94(87.34-123.75)$ a & $645.35(486.83-924.07)$ a & $186.81 ; 0.0001$ & 1 \\
\hline & $\begin{array}{l}\text { Adult } \\
\text { female }\end{array}$ & 224 & $1.15 \pm 0.13$ & $11.12(3.37-22.37) \mathrm{a}$ & $143.56(95.33-207.80)$ a & $1,854.00(1,004.00-5,183.00) b$ & $81.05 ; 0.0001$ & 1 \\
\hline & Adult male & 230 & $1.13 \pm 0.12$ & $10.68(3.26-21.52) \mathrm{a}$ & $145.16(96.99-209.18)$ a & $1,972(1,065-5,502) b$ & $88.54 ; 0.0001$ & 1 \\
\hline \multirow[t]{3}{*}{ Ingestion } & $\begin{array}{l}\text { 5th-instar } \\
\text { nymph }\end{array}$ & 245 & $1.28 \pm 0.17$ & $0.21(0.05-0.45) \mathrm{b}$ & $2.05(1.21-3.12) \mathrm{b}$ & $20.32(11.03-61.69) \mathrm{c}$ & $69.37 ; 0.0001$ & 1 \\
\hline & $\begin{array}{l}\text { Adult } \\
\text { female }\end{array}$ & 270 & $1.32 \pm 0.14$ & $0.21(0.07-0.41) b$ & $1.98(1.31-2.80) \mathrm{b}$ & $18.37(11.06-41.65) \mathrm{c}$ & $84.57 ; 0.0001$ & 1 \\
\hline & Adult male & 280 & $1.94 \pm 0.13$ & $0.42(0.30-0.53) b$ & $1.91(1.63-2.21) b$ & $8.73(7.08-11.29) \mathrm{c}$ & $209.34 ; 0.0001$ & 1 \\
\hline
\end{tabular}

$\mathrm{n}=$ number of insects treated.

The value of each $\chi^{2}$ refers the probability of the angular coefficient $>0$.

LC - values and slopes (in ppm a.i) were estimated by probit procedure (SAS Institute Inc., 2003).

Values followed by the same letter within row are not significantly different if their $95 \%$ CL overlap.

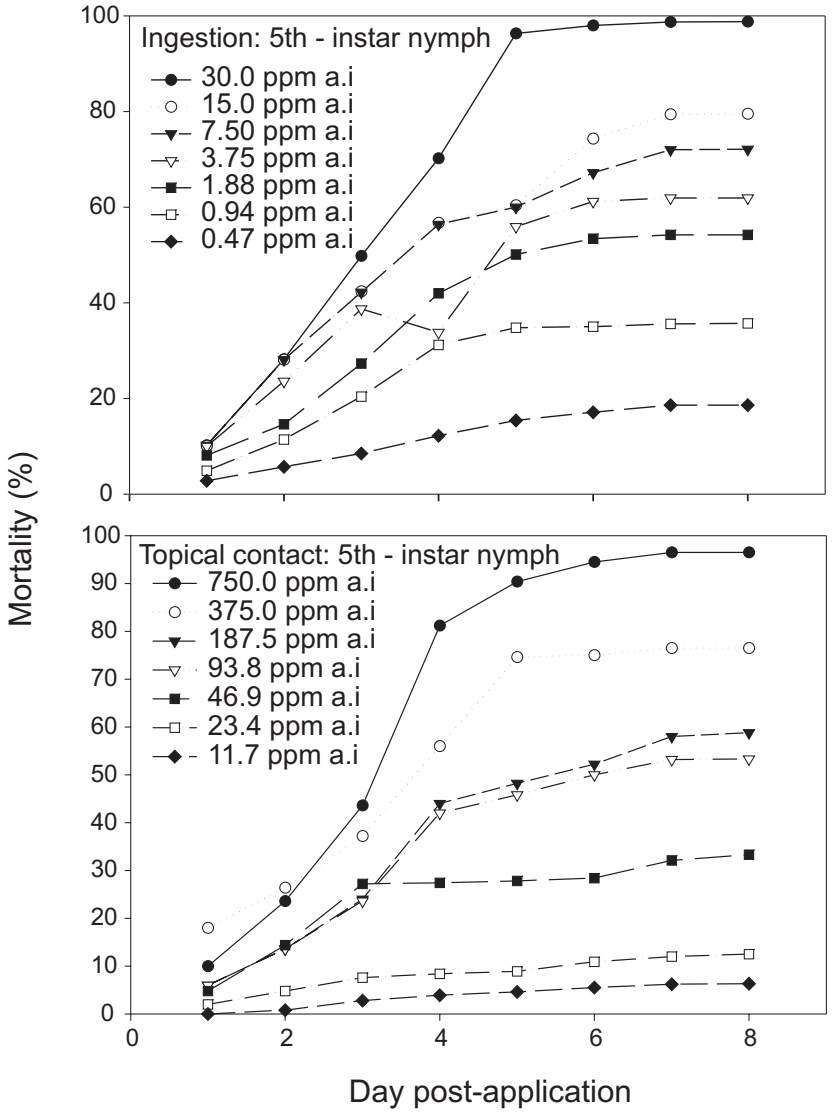

Figure 1 - Average mortality of 5th-instar nymphs of $P$. nigrispinus treated topically $(\mathrm{n}=250)$ and by ingestion $(\mathrm{n}=245)$ with gamma-cyhalothrin.

This insecticide via topical application was relatively harmless for adults of $P$. nigrispinus (females: $\mathrm{LC}_{50}$ $=143.5$ ppm a.i. and males: $\mathrm{LC}_{50}=145.1 \mathrm{ppm}$ a.i), and 5thinstar nymphs $\left(\mathrm{LC}_{50}=103.9 \mathrm{ppm}\right)$ in comparison to via ingestion (females: $\mathrm{LC}_{50}=1.98$ ppm a.i., males: $\mathrm{LC}_{50}=1.91$

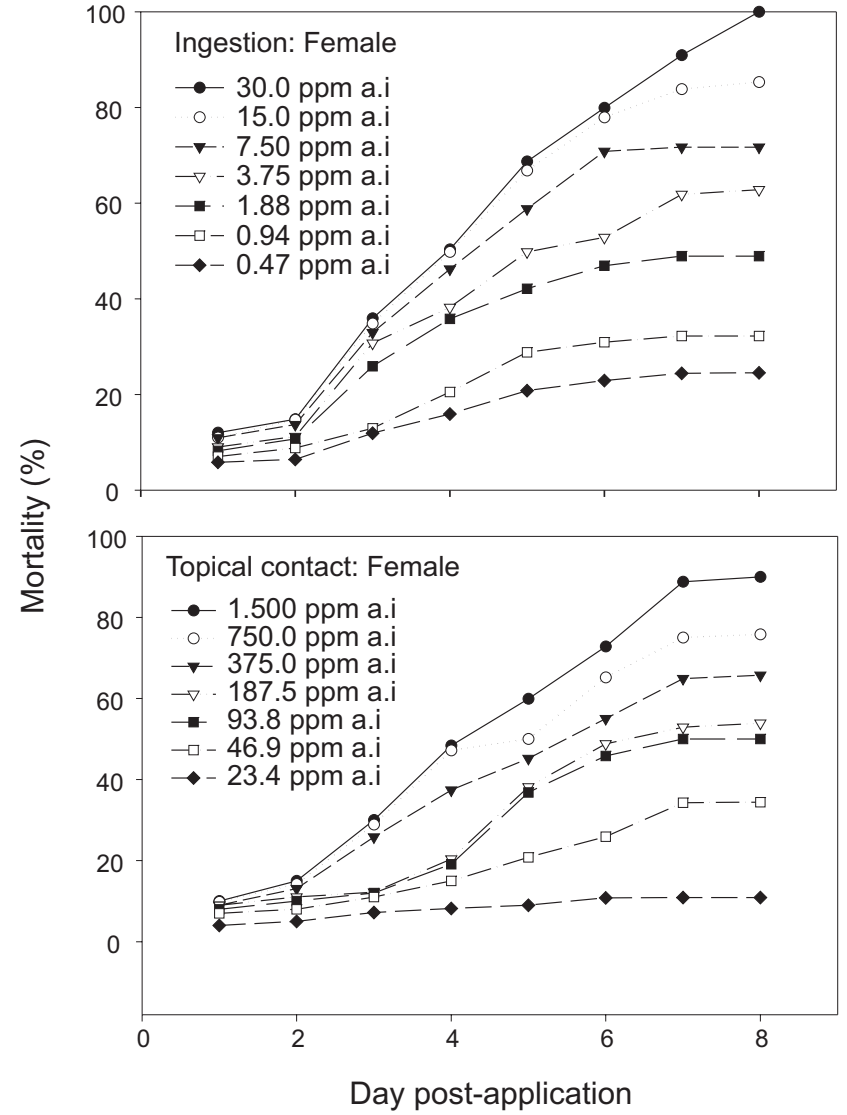

Figure 2 - Average mortality of females of $P$. nigrispinus treated topically $(n=224)$ and by ingestion $(n=270)$ with gamma-cyhalothrin.

ppm a.i., and 5th-instar nymphs: $\mathrm{LC}_{50}=2.05$ ppm a.i.). Therefore, $P$. nigrispinus was more affected by drinking water treated with gamma-cyhalothrin (average $\mathrm{LC}_{50^{\circ} \mathrm{s}}=1.98$ ppm between nymphs and adults) than by topical exposure (average $\mathrm{LC}_{50}$ 's $=130.88 \mathrm{ppm}$ between nymphs and adults). 


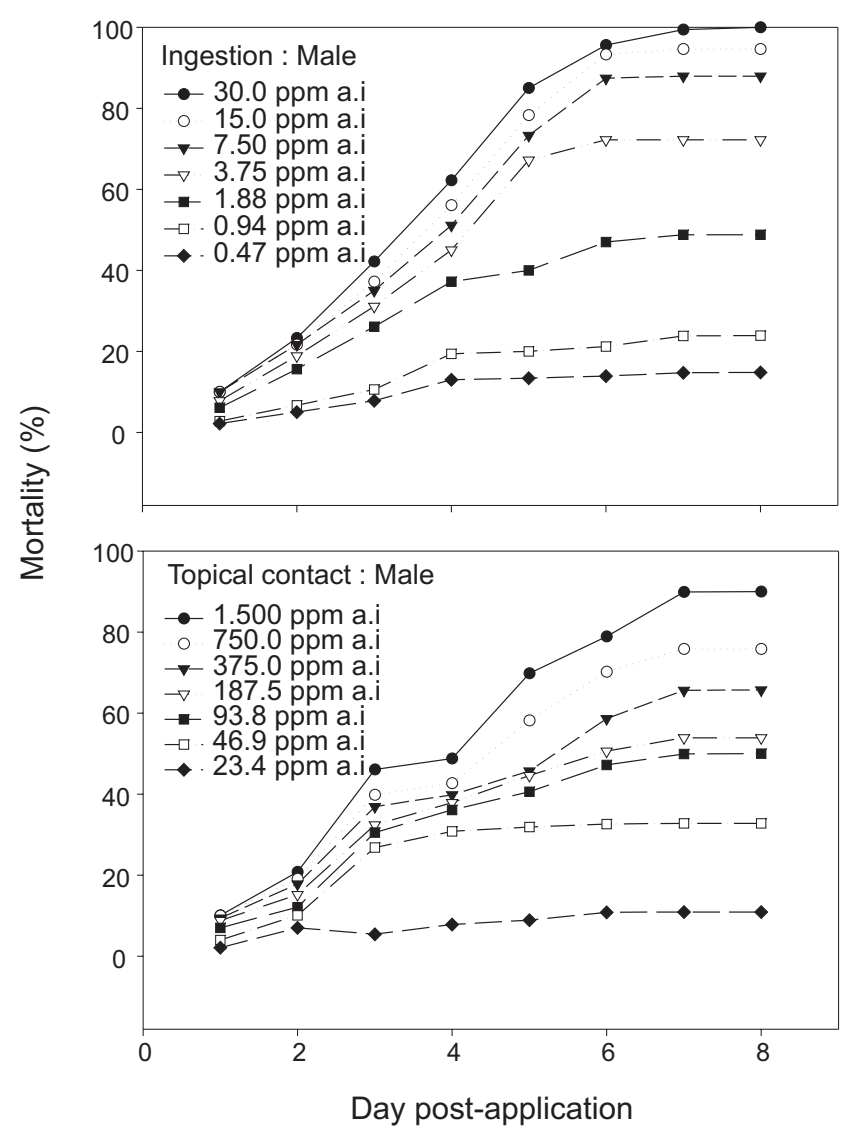

Figure 3 - Average mortality of males of P. nigrispinus treated topically $(\mathrm{n}=230)$ and by ingestion $(\mathrm{n}=280)$ with gamma-cyhalothrin.

\section{DISCUSSION}

Predatory stinkbugs may be affected by insecticide applications via direct and residual contact, or through feeding on contaminated prey or plants. On the other hand, plant feeding has positive implications on predaceous bugs for biological control. Plant material can be an alternative food to maintain populations of omnivorous predators when preys are scarce (Ehler \& Miller, 1978). Phytophagy helps to maintain high population levels of P. nigrispinus (Lemos et al., 2001) because predatory Pentatomidae can obtain moisture and maybe nutrients from plants (De Clercq \& Degheele, 1992). Consequently, these predators may be poisoned by contaminated water or juices from insecticide-treated plants (De Clercq et al., 1995).

Researchers have studied the tolerance of Podisus spp. to insecticides. Podisus maculiventris (Say) nymphs and adults showed high mortality after exposed by tarsal contact to organophosphate insecticides (Wilkinson et al., 1978). P. maculivenntris is more susceptible to organophosphate insecticides sulprofos and profenofos than to pyrethroids fenvalerate and permethrin (Wilkinson et al., 1979). This predator is generally more susceptible to or- ganophosphate and carbamate insecticides than to pyrethroids compared to its prey (Yu, 1988). The pyrethroid insecticides fenvalerate and deltamethrin are less toxic to $P$. nigrispinus than the organophosphate fenitrothion (Guedes et al., 1992). The susceptibility of insects to insecticides will depend on the ability of an insect to handle these compounds and the avoidance of direct contamination or deleterious effects in successive generations can determine the degree of insect resistance.

The pyrethroid gamma-cyhalothrin was more toxic to P. nigrispinus by ingestion than by topical application. This observation corroborates of De Cock et al. (1996), who reported a high toxicity of imidacloprid insecticide to fifth instar nymphs and adults of $P$. maculiventris by ingestion as compared to topical exposure. De Clercq et al. (1995) found higher mortality caused by diflubenzuron in the drinking water to $P$. maculiventris than pyriproxyfen; however diflubenzuron was not active by residual and direct contacts. Benzoylphenyl ureas are more toxic to $P$. nigrispinus by ingestion than by contact or topical application because its absorption through the cuticle is relatively low, and that may explain its selectivity towards beneficial insects (Retnakaran \& Wright, 1987). The exact reason of lower susceptibility of natural enemies such as Podisus spp. to pyrethroids is not well known (Picanço et al., 1997). The hypothesis of a slower penetration of these insecticides through the cuticle of $P$. nigrispinus are discussed because this insect has thicker, lipid-richer cuticle than its prey (Guedes et al., 1992). Therefore, this tolerance may increase the efficiency of $P$. nigrispinus in biological control programs.

Nymphs of $P$. maculiventris were more susceptible after topical exposure to imidacloprid than adults (De Cock et al., 1996) what was also found for $P$. nigrispinus after topical exposure to gamma-cyhalothrin. This may explain the different cuticular penetration rate of insecticides topically applied to P. maculiventris (Yu, 1988). Also, an excess of cuticle may deposit highly lipophilic insecticides, what depends on food intake and its effects on composition of cuticles, especially on lipid content (Ebeling, 1964). The rate of penetration of lipophilic insecticides in the cuticle is slower in adult predators due to their thicker and more rigid cuticle than their nymphs. This reduce the acquisition process and may explain differences on the toxicity of the gamma-cyhalothrin to this predator. Higher toxicity of this insecticide to $P$. nigrispinus via ingestion may be due to the fact that this insecticide enters the circulation and contaminate hemolymph supply. This increases its distribution through the organism without any efficient natural barrier such as the cuticle.

The most common type of resistance is the removal of the insecticide from its site of action by detoxication (Perry \& Agostin, 1974). The biotransformation 
(substances able to neutralize, inactivate, or eliminate foreign organic substances, including poisons or to avoid toxic damage) may involve oxidation, reduction, hydrolytic processes, and synthetic or conjugative reactions (Williams, 1959). Yu (1987) reported higher amount of the detoxication enzymes (microsomal oxidases and esterases) in predatory stinkbugs than in its prey what indicates mechanism of tolerance to insecticides in pentatomids. The selectivity of gamma cyhalothrin to $P$. nigrispinus may be related to the two protection mechanisms herein discussed. However, the combined use of pyrethroids and beneficial insects in IPM programs should be better evaluated.

\section{ACKNOWLEDGMENTS}

To "Conselho Nacional de Desenvolvimento Científico e Tecnológico (CNPq)" and "Fundação de Amparo à Pesquisa do Estado de Minas Gerais (FAPEMIG)" for financial support and fellowships.

\section{REFERENCES}

BOYD, M.L.; BOETHEL, D.J. Susceptibility of predaceous hemipteran species to selected insecticides on soybean in Louisiana. Journal of Economic Entomology, v.91, p.401-409, 1998.

CAMPBELL, C.D.; WALGENBACH, J.F.; KENNEDY, G.G. Effect of parasitoids on lepidopterous pests in insecticide-treated and untreated tomatoes in Western North Carolina. Journal of Economic Entomology, v.84, p.1662-1667, 1991.

DE CLERCQ, P.; DEGHEELE, D. Influence of feeding interval on reproduction and longevity of Podisus sagitta (Het.: Pentatomidae). Entomophaga, v.37, p.583-590, 1992.

DE CLERCQ, P.; DE COCK, A.; TIRRY, L.; VINUELA, E.; DEGHEELE, D. Toxicity of duflubenzuron and pyriproxyfen to the predatory bug Podisus maculiventris. Entomologia Experimentalis et Applicata, v.74, p.17-22, 1995.

DE COCK. A.; DE CLERCQ, P.; TIRRY, L.; DEGHEELE, D. Toxicity of diafenthiuron and imidacloprid to the predatory bug Podisus maculiventris (Heteroptera: Pentatomidae). Biological Control, v.25, p.476-480, 1996.

EBELING, W. The permeability of insect cuticle. In: ROCKSTEIN, M. (Ed.). The physiology of insecta. New York: Academic Press, 1964. p.507-556.

EHLER, L.E.; MILLER, J.C. Biological control in temporary agroecosystems. Entomophaga, v.23, p.207-212, 1978.

FINNEY, D.J. Probit analysis. Cambridge: Cambridge University, 1971. $331 \mathrm{p}$.

GUEDES, R.N.C.; LIMA, J.O.G.; ZANUNCIO, J.C. Seletividade dos inseticidas deltametrina, fenvalerato e fenitrotiom para Podisus connexivus Bergroth, 1891 (Heteroptera: Pentatomidae). Anais da Sociedade Entomológica do Brasil, v.21, p.339-346, 1992.

LEMOS, W.P.; MEDEIROS, R.S.; RAMALHO, F.S.; ZANUNCIO, J.C. Effects of plant feeding on the development, survival, and reproduction of Podisus nigrispinus (Dallas) (Heteroptera: Pentatomidae). International Journal of Pest Management, v.47, p.89-93, 2001.

MEDEIROS, R.S.; RAMALHO, F.S.; LEMOS, W.P.; ZANUNCIO, J.C. Age-dependent fecundity and life-fertility tables for Podisus nigrispinus (Dallas) (Het., Pentatomidae). Journal of Applied Entomology, v.124, p.319-324, 2000.

MEDEIROS, R.S.; RAMALHO, F.S.; SERRÃO, J.E.; ZANUNCIO, J.C. Temperature influence on the reproduction of Podisus nigrispinus, a predator of the noctuid larva Alabama argillacea. BioControl, v.48, p.695-704, 2003
MESTDAGH, I.; DE CLERCQ, P.; DEGHEELE, D. Susceptibility of the predatory bug Podisus maculiventris (Say) (Heteroptera: Pentatomidae) to pyriproxyfen residues on sweet pepper plants. Parasitica, v.52, p.153$161,1996$.

MOHAGHEGH, J.; DE CLERCQ, P.; TIRRY, L. Toxicity of selected insecticides to the spined soldier bug, Podisus maculiventris (Heteroptera: Pentatomidae). Biological Science \& Technology, v.10, p.33-40, 2000 .

PERRY, A.S.; AGOSTIN, M. The physiology of insecticide resistance by insects. In: ROCKSTEIN, M. (ed). The physiology of insecta. New York: Academic Press, 1974. p.121, 1974.

PICANCCO, M.; RIBEIRO, L.J.; LEITE, G.L.D.; ZANUNCIO, L.C. Seletividade de inseticidas a Podisus nigrispinus predador de Ascia monuste orseis. Pesquisa Agropecuária Brasileira, v.32, p.369-372, 1997.

RAMALHO, F.S. Cotton pest management: part. 4. A Brazilian perspective. Annual Review of Entomology, v.39, p.553-578, 1994.

RAMALHO, F.S.; MEDEIROS, R.S.; LEMOS, W.P.; WANDERLEY, P.A.; DIAS, J.M.; ZANUNCIO J.C. Evaluation of Catolaccus grandis (Burks) (Hymenoptera: Pteromalidae), as a biological control agent against cotton boll weevil. Journal of Applied Entomology, v.124, p.359-364, 2000.

RETNAKARAN, A.; WRIGHT, J.E. Control insect pests with benzoylphenyl ureas. In. WRIGHT, J.E.; RETNAKARAN, A. (Ed.). Chitin and benzoylphenyl ureas. Dordrecht: Dr. W. Junk Publications, 1987. p.205-282.

RUBERSON, J.R.; HERZOG, G.A.; LAMBERT, W.R.; LEWIS, W.J. Management of the beet armyworm (Lepidoptera: Noctuidae) in cotton: role of natural enemies. Florida Entomologist, v.77, p.440-453, 1994.

SAS INSTITUTE. Sas user's guide: statistics. Cary: SAS Institute, 2003. 846p.

SMAGGHE, G.; DEGHEELE, D. Selectivity of nonsteroidal ecdysteroid agonists RH 5849 and RH 5992 to nymphs and adults of predatory soldier bugs, Podisus nigrispinus and P. maculiventris (Hemipera: Pentatomidae). Journal of Economic Entomology, v.88, p.40-45, 1995.

STEHR, F.W. Parasitoids and predators in pest management. In: METCALF, R.M.; LUCKMANN, H.L. (Ed.). Introduction to insect pest management. New York: J. Wiley, 1982. p.135-173.

TILLMAN, P.G.; MULROONEY, J.E. Effect of selected insecticides on the natural enemies Coleomegilla maculata and Hippodamia convergens (Coleoptera: Coccinelidae), Geocoris puncticipes (Hemiptera: Lygaeidae), and Bracon mellitor, Cardiochiles nigriceps, and Cotesia marginiventris (Hymenoptera: Braconidae) in cotton. Journal of Economic Entomology, v.93, p.1638-1643, 2000.

WHITCOMB, J.R.; BELL, K.O. Efficiency of egg predators of the bollworm. Arkansas Farmer Research, v.11, p.23-31, 1962.

WILKINSON, J.D.; BIEVER, K.D.; IGNOFFO, C.M.; PONS, W.J.; MORRISON, R.K.; SEAY, R.S. Evaluation of diflubenzuron formulations on selected insect parasitoids and predators. Journal of Georgia Entomology Society, v.13, p.227-236, 1978.

WILKINSON, J.D.; BIEVER, K.D.; IGNOFFO, C.M. Synthetic pyrethroid and organophosphate insecticides against the parasitoid Apanteles marginiventris and the predators Geocoris punctipes, Hyppodamia convergens, and Podisus maculiventris. Journal of Economic Entomology, v.72, p.473-475, 1979.

WILLIAMS, R.T. Detoxication mechanisms. New York: Wiley, 1959. 358p.

YU, S.J. Chemical defense capacity in the spinner soldier bug (Podisus maculiventris) and its lepidopterous prey. Pest Biochemistry Physiology, v.28, p.216-223, 1987.

YU, S. Selectivity of insecticides to the spinned soldier bug (Heteroptera: Pentatomidae) and its lepidopterous prey. Journal of Economic Entomology, v.81, p.119-122, 1988.

ZANUNCIO, T.V.; SERRÃO, J.E.; ZANUNCIO, J.C.; GUEDES, R.N.C. Permethrin-induced hormesis on the predator Supputius cincticeps (Stål, 1860) (Heteroptera: Pentatomidae). Crop Protection, v.22, p.941-947, 2003.

Received November 19, 2004

Accepted August 25, 2005 